\title{
Role of Na,K-ATPase in Regulating Acidification of Early Rat Liver Endocytic Vesicles
}

\author{
MaAn ANBaRi, KaRen V. ROOT and Rebecca W. Van DyKe \\ Division of Gastroenterology, Department of Medicine, University of Michigan School of Medicine, Ann Arbor, Michigan \\ 48109-0682
}

\begin{abstract}
Endocytic vesicles are acidified by an electrogenic proton pump and a parallel chloride conductance; however, acidification might be decreased if electrogenic transporters, such as $\mathrm{Na}, \mathrm{K}$-ATPase, that increase vesicle interior-positive membrane potential were also present. We examined this issue in early rat liver endosomes using ion substitution and inhibitors to alter Na,K-ATPase activity. These early endosomes, labeled for $2 \mathrm{~min}$ with the fluorescent fluid-phase marker fluorescein isothiocyanate-dextran, consistently acidified faster than endosomes similarily labeled for a 10-min period. In chloride-free media initial rates of acidification of early endosomes were faster in $\mathrm{K}^{+}$media than in $\mathrm{Na}^{+}$medium, although addition of $\mathrm{K}^{+}$to $\mathrm{Na}^{+}$or $\mathrm{Na}^{+}$to $\mathrm{K}^{+}$media to allow $\mathrm{Na}, \mathrm{K}-\mathrm{ATP}$ ase to function did not decrease the rate of acidification. In chloride-containing media, rates were the same regardless of cation composition. The $\mathrm{Na}, \mathrm{K}$-ATPase inhibitor vanadate was prepared from orthovanadate by several methods, all of which inhibited liver ATPase activity. Two hundred $\mu \mathrm{mol} / \mathrm{L}$ vanadate, prepared $\mathrm{Cl}^{-}$free, tended to decrease rates of acidification in all media tested and these effects achieved statistical significance in $\mathrm{Cl}^{-}$-free media containing $150 \mathrm{mmol} / \mathrm{L}$ $\mathrm{K}^{+}$or mixtures of $\mathrm{Na}^{+}$and $\mathrm{K}^{+}$and in $145 \mathrm{mmol} / \mathrm{L} \mathrm{KCl} / 5$ mmol/L NaCl medium. Vanadate stocks pH-adjusted with hydrogen chloride increased rates of acidification in sodium gluconate buffers, probably as a result of the effects of the included $\mathrm{Cl}^{-}$. Five $\mathrm{mmol} / \mathrm{L}$ ouabain (loaded into vesicles by endocytosis) and the membrane-permeable analog strophanthidin ( $2 \mathrm{mmol} / \mathrm{L}$ ) both markedly inhibited endosome acidification, regardless of buffer ion composition. Collectively, these results suggest that $\mathrm{Na}, \mathrm{K}$-ATPase does not regulate acidification of rat liver early endocytic vesicles, that
\end{abstract}

Received July 19, 1993; accepted November 17, 1993.

This work was carried out with the technical assistance of Loretha L. Ervin. This work was supported by a grant from the National Institutes of Health (DK 38333) to Dr. Van Dyke.

This work was presented at the annual meeting of the American Gastroenterological Association, May 16, 1993, in Boston, and published in abstract form (Gastroenterology 1993;104:A870).

Address reprint requests to: Dr. Rebecca W. Van Dyke, M.D., 6520 MSRB-I, University of Michigan Medical Center, 1150 W. Medical Center Dr., Ann Arbor, MI 48109-0682.

Copyright (c) 1994 by the American Association for the Study of Liver Diseases.

$0270-9139 / 94 \$ 1.00+.10 \quad \mathbf{3 1} / \mathbf{1} / \mathbf{5 3 1 9 4}$ vanadate may modestly inhibit endosome acidification and that ouabain at high concentrations may inhibit acidification from the vesicle interior face. (HEPATOLOGY 1994;19:1034-1043.)

Vesicular acidification is important for many organelle processes such as receptor-mediated endocytosis and recycling of receptors, lysosomal degradation and intracellular membrane traffic. Acidification of intracellular endocytic vesicles mediated by an electrogenic $\mathrm{H}^{+}$-ATPase is usually facilitated by a parallel $\mathrm{Cl}^{-}$ conductance that dissipates electrical gradients (1-3). Theoretically, an increase in the interior positive vesicle membrane potential $(\Delta \psi)$ would be expected to decrease acidification (3). Na,K-ATPase, an electrogenic pump located on liver basolateral membranes (4), would be expected to generate a positive intravesicular $\Delta \psi$ if incorporated into early endosomes, as it would be oriented to pump $\mathrm{Na}^{+}$into vesicle interiors, and thus to decrease acidification in the presence of both $\mathrm{Na}^{+}$and $\mathrm{K}^{+}$, especially in the absence of permeable anions such as $\mathrm{Cl}^{-}$.

In previous studies, functional $\mathrm{Na}, \mathrm{K}$-ATPase was detected in endosomes of Chinese hamster ovary cells (5), Swiss 3T3 cells (6) and epidermoid carcinoma cells (7), but not in erythroleukemia cells (8) or rabbit kidney (9). Because the $\beta$ subunit of $\mathrm{Na}, \mathrm{K}$-ATPase has been immunologically localized to rat liver endosomes $(10,11)$, we tested whether $\mathrm{Na}, \mathrm{K}$-ATPase plays a role in altering acidification of rat liver endosomes by using a variety of $\mathrm{Na}, \mathrm{K}-\mathrm{ATP}$ ase inhibitors (vanadate, ouabain, strophanthidin) and changes in medium ion composition. Because "early" endosomes are most likely to contain $\mathrm{Na}, \mathrm{K}$-ATPase, we studied vesicles that were loaded with FITC-dextran, a marker of fluid-phase endocytosis, for $2 \mathrm{~min}$ or less.

\section{MATERIALS AND METHODS}

Materials. All chemicals except ATP (Boehringer Mannheim, Indianapolis, IN) and antifluorescein antibody (Molecular Probes, Inc., Eugene, OR) were purchased from Sigma Diagnostics (St. Louis, MO). Carbonyl cyanide m-chlorophenylhydrazone (CCCP), monensin and strophanthidin were prepared as stock solutions in ethanol. Vanadate was prepared as three different stocks. For one, sodium orthovanadate was dissolved in $100 \mathrm{mmol} / \mathrm{L}$ sodium hydroxide and allowed to 
equilibrate for several days before use ( $\mathrm{NaOH}$ vanadate) (12). For the others, orthovanadate was dissolved in water, the $\mathrm{pH}$ was adjusted to 10.0 with concentrated $\mathrm{HCl}\left(\mathrm{Cl}^{-}\right.$vanadate) or $\mathrm{H}_{2} \mathrm{SO}_{4}\left(\mathrm{SO}_{4}^{-2}\right.$ vanadate) and boiled to destroy polymeric vanadate species (13). Before use, $70,000 \mathrm{~mol}$ wt FITC-conjugated dextran (FITC-dextran) was purified by dialysis for 4 to 5 days against $20 \mathrm{mmol} / \mathrm{L}$ phosphate buffer $(\mathrm{pH}$ 7.0 ), lyophilized and stored at $-20^{\circ} \mathrm{C}$. All animals used in these studies received humane care in compliance with the University of Michigan guidelines.

Isolated Endosomes. Early ("2-min") liver endosomes were prepared in a microsomal pellet from 250 -gm male SpragueDawley rats analogous to the preparation of 10 -minute endosomes as previously described (14). Two-minute endosomes were defined as sealed vesicular structures that contained FITC-dextran. Briefly, 2 min after intravenous injection of $50 \mathrm{mg} 70,000 \mathrm{~mol}$ wt FITC-dextran dissolved in 1-ml normal saline solution, livers were rapidly chilled and intravascular FITC-dextran was removed by rapid perfusion through the portal vein of 100 to $200 \mathrm{ml}$ ice-cold sucrose buffer $(250$ $\mathrm{mmol} / \mathrm{L}$ sucrose, $3 \mathrm{mmol} / \mathrm{L}$ imidazole) ( $\mathrm{pH} \mathrm{7.4)}$ ). Livers were removed, chopped into small pieces ( 1 to $2 \mathrm{~mm}$ ) with scalpels and homogenized in 5 vol of ice-cold sucrose buffer by six passes of a loose-fitting Dounce homogenizer and one pass of a tight-fitting Dounce. Homogenates were centrifuged at 1,000 $g_{a v}$ for $10 \mathrm{~min}$ to remove nuclei and unbroken cells. Supernatants were removed and centrifuged at $10,000 \mathrm{~g}_{a i}$ for $20 \mathrm{~min}$. Supernatants were removed and a microsomal pellet that contained fluorescent endosomes was prepared by centrifugation at $100,000 \mathrm{~g}_{a v}$ for $60 \mathrm{~min}$. Pellets were resuspended in isotonic buffers containing $140 \mathrm{mmol} / \mathrm{L}$ potassium gluconate or $140 \mathrm{mmol} / \mathrm{L}$ sodium gluconate, $30 \mathrm{mmol} / \mathrm{L}$ bis $[2$ hydroxyethyl] imino-tris [hydroxymethyl] methane (BIS-TRIS) $(\mathrm{pH}$ 7.0 ) with 5 to 7 passes of a loose Dounce homogenizer and kept on ice until used. In selected studies, we also prepared endosomes loaded for $10 \mathrm{~min}$ with FITC-dextran. Because endosomes were not purified, all studies of endosome function used the fluorescence of internalized FITC-dextran.

Liver Perfusion. Rat livers were isolated and perfused with isotonic buffer $(103 \mathrm{mmol} / \mathrm{L} \mathrm{NaCl}, 4.6 \mathrm{mmol} / \mathrm{L} \mathrm{KCl}, 2.1$ $\mathrm{mmol} / \mathrm{L} \mathrm{MgCl}_{2}, 2.4 \mathrm{mmol} / \mathrm{L} \mathrm{CaCl}{ }_{2}, 25 \mathrm{mmol} / \mathrm{L} \mathrm{NaHCO}_{3}, 10$ $\mathrm{mmol} / \mathrm{L}$ glucose, $3 \%$ hydroxyethyl starch) containing the oxygen carrier perfluorotributylamine (Oxypherol-E.T.) as previously described (15) for a total of $25 \mathrm{~min}$. After $5 \mathrm{~min}$ of perfusion, $1 \mathrm{mmol} / \mathrm{L}$ sodium nitroprusside was added to the perfusate of all livers to prevent ouabain-induced vasospasm (16). After a further 10-min equilibration period, all perfusates were switched either to the same Fluosol-containing buffer with nitroprusside (control livers) or to Fluosol-containing buffer with nitroprusside plus $5 \mathrm{mmol} / \mathrm{L}$ ouabain (ouabaintreated livers). After another 5 -min observation period, $150 \mathrm{mg}$ FITC-dextran was added to the perfusate of each liver. Five minutes later livers were rapidly flushed and chilled by perfusion with ice-cold sucrose buffer $(250 \mathrm{mmol} / \mathrm{L}$ sucrose, $3 \mathrm{mmol} / \mathrm{L}$ imidazole) ( $\mathrm{pH}$ 7.4) and " 5 -min" endosomes that had internalized FITC-dextran with or without ouabain were prepared as a microsomal pellet as described for 2-minute endosomes. During all perfusions bile was collected in 5-min aliquots and perfusion pressure monitored at 5-min intervals. All perfusions were carried out as paired studies using age-matched littermates, such that one control and one ouabain liver were perfused each day.

Vesicle Acidification. Initial rates of ATP-dependent vesicle acidification and steady-state intravesicular $\mathrm{pH}\left(\mathrm{pH}_{\mathrm{i}}\right)$ were assessed from the ratio of fluorescein fluorescence at two excitation wavelengths (excitation, $493 \mathrm{~nm}, 450 \mathrm{~nm}$; emission,
$530 \mathrm{~nm}$ ) using a dual-wavelength computer-controlled spectrofluorometer (SPEX Industries, Edison, NJ) (14, 17). For these studies, aliquots of vesicles loaded with FITC-dextran were suspended in $2-\mathrm{ml}$ buffer $(140 \mathrm{mmol} / \mathrm{L}$ potassium or $\mathrm{Na}$ salts, $30 \mathrm{mmol} / \mathrm{L}$ BIS-TRIS [ $\mathrm{pH} 7.0$ ] with various combinations of $\mathrm{Cl}^{-}$and gluconate) in acrylic disposable cuvettes and preincubated at $22^{\circ} \mathrm{C}$ for $5 \mathrm{~min}$ with solvent or vanadate or strophanthidin, as indicated in figure legends. Cuvettes then were placed in a temperature-controlled chamber at $22^{\circ} \mathrm{C}$ in the SPEX fluorometer and fluorescence was recorded at 1-sec intervals. Sufficient amounts of antifluorescein antibody ( 10 to $20 \mu \mathrm{g}$ per $2-\mathrm{ml}$ assay) were added to cuvettes to quench fluorescence of any extravesicular fluorescein. Acidification assays were initiated by the addition of $5 \mathrm{mmol} / \mathrm{L} \mathrm{Mg} \mathrm{ATP}$ and were followed until steady state $\mathrm{pH}_{\mathrm{i}}$ was achieved. Proton ionophores (monensin $[13.3 \mu \mathrm{mol} / \mathrm{L}]$ and CCCP $[3.4 \mu \mathrm{mol} / \mathrm{L}]$ ) were then added to eliminate $\mathrm{pH}$ gradients and a three-point standard curve relating $\mathrm{pH}$ to fluorescence ratio was determined by sequential addition of aliquots of acid and measurement of buffer $\mathrm{pH}$ and fluorescence ratio. Each plot of fluorescence ratio vs. time was converted to a plot of $\mathrm{pH}_{\mathrm{i}} \mathrm{vs}$. time using the standard curve determined for that assay. Initial rates of ATP-dependent acidification were calculated from the slope of a line fit by eye to the initial portion of the tracing after addition of MgATP, and steady-state $\mathrm{pH}_{\mathrm{i}}$ was taken as the lowest stable value. To allow precise control of buffer $\mathrm{K}^{+}$and $\mathrm{Na}^{+}$composition, $\mathrm{pH}$ adjustments to solutions were made with concentrated stocks of tetramethylammonium hydroxide (TMA-OH) or $\mathrm{H}_{3} \mathrm{PO}_{4}$ and the $\mathrm{Mg}$ salt of ATP was used. All assays contained $0.2 \mathrm{mmol} / \mathrm{L} \mathrm{K}^{+}$from the antifluorescein antibody solution and $0.8 \mathrm{mmol} / \mathrm{L} \mathrm{Na}^{+}$was added to most control experiments to account for the $\mathrm{Na}^{+}$load of sodium orthovanadate dissolved in $\mathrm{NaOH}$. Preliminary studies showed that this amount of sodium did not alter acidification rates.

Proton Leak Rates. Proton leak rates were measured in endocytic vesicles as previously described (14). In brief, after endosomes had acidified to steady-state $\mathrm{pH}_{i}$, the proton pump was rapidly and completely stopped by addition of $1 \mu \mathrm{mol} / \mathrm{L}$ bafilomycin, a specific inhibitor of this proton pump. The initial rate of realkalinization of endosomes was taken as the proton leak rate (expressed as $\mathrm{pH}$ units per minute). Leak rates were normalized by dividing by the extravesicular-to-intravesicular gradient of hydrogen ions and expressed as $\mathrm{pH}$ units per minute per $\mu \mathrm{mol} / \mathrm{L}$ hydrogen ions. Studies were performed in high- $\mathrm{K}^{+}$media $(140 \mathrm{mmol} / \mathrm{L}$ potassium gluconate and 135 $\mathrm{mmol} / \mathrm{L} \mathrm{K}^{+} / 5 \mathrm{mmol} / \mathrm{L} \mathrm{Na}{ }^{+}$gluconate) and in high- $\mathrm{Na}^{+}$media $\left(140 \mathrm{mmol} / \mathrm{L} \mathrm{Na}\right.$ gluconate and $135 \mathrm{mmol} / \mathrm{L} \mathrm{Na}^{+} / 5 \mathrm{mmol} / \mathrm{L} \mathrm{K}^{+}$ gluconate) with or without $200 \mu \mathrm{M} \mathrm{Cl}^{-}$-free boiled vanadate. Because results were similar for all high- $\mathrm{K}^{+}$media (and for all high $-\mathrm{Na}^{+}$media) (data not shown), results obtained in 140 $\mathrm{mmol} / \mathrm{L} \mathrm{K}$ gluconate and $135 \mathrm{mmol} / \mathrm{L} \mathrm{K}^{+} / 5 \mathrm{mmol} / \mathrm{L} \mathrm{Na}{ }^{+}$ gluconate were combined as were results obtained in 140 $\mathrm{mmol} / \mathrm{L}$ sodium gluconate and $135 \mathrm{mmol} / \mathrm{L} \mathrm{Na}{ }^{+} / 5 \mathrm{mmol} / \mathrm{L} \mathrm{K}^{+}$ gluconate.

Coupled-enzyme ATPase Assay. ATPase activity at $37^{\circ} \mathrm{C}$ was measured in frozen $\left(-70^{\circ} \mathrm{C}\right)$ and thawed aliquots of liver microsomes using a continuously recording spectrophotometer (DU-64, Beckman, Arlington Heights, IL) and a coupled enzyme system that regenerates ATP and couples ATP hydrolysis to oxidation of NADH (18). Each assay contained (in a total volume of $1 \mathrm{ml}$ ) $2.1 \mathrm{mmol} / \mathrm{L}$ phosphoenolpyruvate, 0.33 $\mathrm{mmol} / \mathrm{L} \mathrm{NADH}, 5$ units pyruvate kinase, 6.9 units lactic dehydrogenase, $0.95 \mathrm{ml}$ buffer $(130 \mathrm{mmol} / \mathrm{L}$ Tris, $1 \mathrm{mmol} / \mathrm{L}$ EGTA, $125 \mathrm{mmol} / \mathrm{L} \mathrm{NaCl}, 13 \mathrm{mmol} / \mathrm{L} \mathrm{KCl}, 5 \mathrm{mmol} / \mathrm{L} \mathrm{NaN}_{3}$ ), and 175 to $340 \mu \mathrm{g}$ microsome protein. This mixture was 


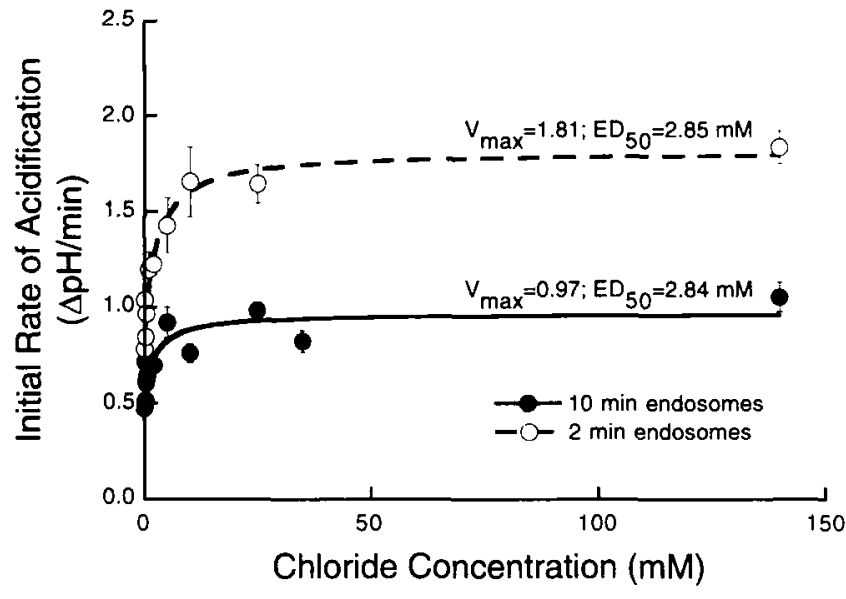

FIG. 1. Initial rates of acidification of rat liver endosomes prepared after a 2-min (0) or 10-min ( $\bullet$ exposure to FITC-dextran measured in media containing $140 \mathrm{mmol} / \mathrm{L}$ potassium salts (mixtures of gluconate and $\mathrm{Cl}^{-}$to achieve indicated $\mathrm{Cl}^{-}$concentrations), $30 \mathrm{mmol} / \mathrm{L} \mathrm{BIS}$ TRIS, $\mathrm{pH} 7.0$ after addition of $5 \mathrm{mmol} / \mathrm{L} \mathrm{MgATP}$. Symbols represent mean \pm S.E.M. of values measured in three to eight separate preparations of $2-\mathrm{min}$ endosomes and in four to 55 preparations of 10-min endosomes (some 10-min endosome data also appeared in Figure 4A of reference 14; however, this graph reflects addition of data from ten other preparations of 10-min endosomes). A MichaelisMenten function of the form $y=(a x /[b+x])+c$ was fit to data and constants estimated. $a+c$ was taken to represent $\mathrm{V}_{\max }$ and $\mathrm{b}$ the $\mathrm{ED}_{50}$ for $\mathrm{Cl}^{-}$.

preincubated at $37^{\circ} \mathrm{C}$ for $5 \mathrm{~min}$ and the assay was begun by addition of $5 \mathrm{mmol} / \mathrm{L} \mathrm{MgATP}$. ATPase activity was calculated from the slope of the linear rate of decrease of NADH absorbance at $340 \mathrm{~nm}$ (18). To determine the effects of ouabain or vanadate, $5 \mathrm{mmol} / \mathrm{L}$ ouabain or $200 \mu \mathrm{mol} / \mathrm{L}$ vanadate was added to microsomes during the preincubation period. Control assays received vanadate solvent. In preliminary studies we showed that vanadate had no effects on the coupling enzymes (data not shown). Because vanadate may directly oxidize $\mathrm{NADH}(12)$, we performed assays without vanadate or with vanadate in both the presence and absence of MgATP and ATPase activities were corrected for the rates of NADH oxidation measured in equivalent assays containing vanadate but no MgATP. Activity in the latter assays averaged $7.6 \pm 0.6 \%(n=12)$ of total endosome ATPase activity.

Timed Incubation ATPase Assay. Microsome protein 1.2- to 2.5-mg was preincubated for 10 minutes in $3.85 \mathrm{ml}$ of assay buffer (the same electrolyte buffer as was used for the coupled enzyme assay) at $37^{\circ} \mathrm{C}$ in a metabolic water bath (Precision Scientific; Fisher Inc., Chicago, IL) at 100 oscillations/min. The assay was begun by addition of $4 \mathrm{mmol} / \mathrm{L} \mathrm{MgATP}$ and terminated after $10 \mathrm{~min}$ by addition of $1 \mathrm{ml}$ of $30 \%$ trichloroacetic acid. Tubes were centrifuged at 3,500 rpm for $15 \mathrm{~min}$ and $2 \mathrm{ml}$ of supernatant was used for phosphorus determinations by the Fiske and Subbarow method (18). As in the coupled enzyme assay, $5 \mathrm{mmol} / \mathrm{L}$ ouabain, $200 \mu \mathrm{mol} / \mathrm{L}$ vanadate, $1.5 \mathrm{mmol} / \mathrm{L}$ strophanthidin or inhibitor solvent were added to microsome protein during the preincubation period. Preliminary studies established that this assay was linear over the times and protein concentrations we used.

Determination of $\mathrm{Cl}^{-}$Concentration in Vanadate-containing Buffers. We measured the $\mathrm{Cl}^{-}$concentration in vanadate-containing solutions using a spectrophotometric method in which $\mathrm{Cl}^{-}$displaces $\mathrm{SCN}^{-}$from $\mathrm{Hg}(\mathrm{SCN})_{2}$ and the displaced $\mathrm{SCN}^{-}$is detected as the colored complex $\mathrm{Fe}(\mathrm{SCN})^{+2}$ at $460 \mathrm{~nm}$ (19). In our hands this assay reliably detected $\mathrm{Cl}^{-}$ as low as $0.1 \mathrm{mmol} / \mathrm{L}$. Because gluconate interfered with the assay (data not shown), we diluted the $100 \mathrm{mmol} / \mathrm{L}$ vanadate stocks into water rather than into $\mathbf{K}$ gluconate/BIS-TRIS buffer for measurement of $\mathrm{Cl}^{-}$.

Calculations and Statistics. Results were expressed as the mean \pm S.E.M. $(\mathbf{n} \geq 3$ ). Comparisons between experimental and control assays were analyzed using paired and unpaired $t$ tests. Statistical significance was taken as $\mathrm{p}<0.05$. Plots of initial rates of acidification vs. medium $\mathrm{Cl}^{-}$concentration were fitted by nonlinear curve-fitting (Kaleida Graph 2.1; Synergy Software, Reading, PA) on a MacIntosh IIcx computer to a function of the form $y=(a x /[b+x])+c$ and estimates for constants obtained. This represents a form of a MichaelisMenten function in which $\mathrm{c}$ represents the rate of acidification in the absence of chloride, a represents the maximum incremental rate of acidification resulting from chloride $\left(V_{\max }\right), a+c$ represents the overall maximum rate of acidification $\left(V_{\max }\right)$ and $b$ represents the $\mathrm{ED}_{50}$ for $\mathrm{Cl}^{-}(14)$.

\section{RESULTS}

Endosomes were loaded with FITC-dextran for $2 \mathrm{~min}$ to allow us to study acidification of populations of early endosomes. This was the earliest population we could reproducibly prepare because intravenous exposure of rat livers to FITC-dextran for shorter periods of time often yielded too few FITC-dextran-containing vesicles to allow accurate measurement of acidification (data not shown). Although these early endosomes could not be purified and were prepared as a microsomal preparation, acidification studies were based on changes in the fluorescence of internalized FITC-dextran and thus our results reflect proton transport only in those endocytic vesicles that formed from hepatocyte basolateral plasma membranes during the 2-min period in which FITCdextran was in the circulation.

When compared with rat liver endosomes loaded with FITC-dextran for a 10-min period that we have used extensively in other studies $(14,17)$, these 2-min endosomes consistently acidified in a similar manner, but at a more rapid rate, in both the presence and absence of chloride (Fig. 1), consistent with our previous observations that late endosomes and lysosomes acidify more slowly than vesicles earlier in the endocytic pathway (14). This may reflect, in part, the probably smaller size (and greater surface-to-volume ratio) of very early endosomes in contrast to "later" endosomes that are the product of fusion and remodeling.

In the present studies, endosome acidification was assayed in media containing $\mathrm{K}^{+}$or $\mathrm{Na}^{+}$as the sole cation or in mixtures of the two to facilitate $\mathrm{Na}$, K-ATPase activity. In media with the relatively impermeable gluconate as the sole anion, initial rates of acidification in the absence of vanadate were $80 \%$ to $98 \%$ higher in $\mathrm{K}^{+}(150 \mathrm{mmol} / \mathrm{L})$ medium or in high- $\mathrm{K}^{+}(145$ $\mathrm{mmol} / \mathrm{L}) / \mathrm{low}-\mathrm{Na}^{+}(5 \mathrm{mmol} / \mathrm{L})$ medium than in $\mathrm{Na}^{+}(150$ $\mathrm{mmol} / \mathrm{L})$ medium or in high- $\mathrm{Na}^{+}(145 \mathrm{mmol} / \mathrm{L}) / \mathrm{low}-\mathrm{K}^{+}$ $(5 \mathrm{mmol} / \mathrm{L})$ medium $(\mathrm{p}<0.01)$ (Figure $2 \mathrm{~A})$. In chloridecontaining media, there was no difference in acidifcation rates between the various $\mathrm{Na}^{+}$and $\mathrm{K}^{+}$media and 
rates were $195 \%$ to $483 \%$ faster than those in analogous gluconate media ( $p<0.001$ for all four sets of comparisons) (Fig. 2A and $\mathrm{C}$ ). These results suggest that $\mathrm{Na}^{+}$is a less permeable cation than $\mathrm{K}^{+}$and that $\mathrm{Na}^{+}$ efflux from endosomes is less efficient than $\mathrm{K}^{+}$efflux in neutralizing the intravesicular positive $\Delta \psi$ of pumped protons. $\mathrm{Cl}^{-}$appears to be a much more efficient charge-compensating ion than either $\mathrm{K}^{+}$or $\mathrm{Na}^{+}$.

Preincubation of endosomes with $200 \mu \mathrm{mol} / \mathrm{L}$ $\mathrm{Cl}^{-}$-free vanadate, prepared either in concentrated $\mathrm{NaOH}$ ( $\mathrm{NaOH}$ vanadate) or by boiling ( $\mathrm{SO}_{4}{ }^{-2}$ vanadate), decreased rates of acidification by $8 \%$ to $16 \%$, regardless of the ionic composition of the assay medium and these differences achieved statistical significance in $\mathrm{Cl}^{-}$-free media containing $\mathrm{K}^{+}$or $\mathrm{K}^{+}$and $\mathrm{Na}^{+}(\mathrm{p}<0.05$, $\mathrm{p}<0.01)$ and in $145 \mathrm{mmol} / \mathrm{L} \mathrm{KCl} / 5 \mathrm{mmol} / \mathrm{L} \mathrm{NaCl}$ medium ( $<<0.05$ ) (Fig. 2B and C). In contrast, vanadate prepared by boiling after $\mathrm{pH}$ adjustment with $\mathrm{HCl}\left(\mathrm{Cl}^{-}\right.$vanadate) increased the rate of acidification in $150 \mathrm{mmol} / \mathrm{L} \mathrm{Na}$ gluconate medium and in $145 \mathrm{mmol} / \mathrm{L}$ $\mathrm{Na}$ gluconate $/ 5 \mathrm{mmol} / \mathrm{L} \mathrm{K}$ gluconate medium by $85 \%$ to $94 \%$ ( $\mathrm{p}<0.05, \mathrm{p}<0.005$ ), to rates close to those measured in $150 \mathrm{mmol} / \mathrm{L} \mathrm{K}$ gluconate medium (Fig. 2B). None of the vanadate preparations increased acidification in high-Cl ${ }^{-}$media (Fig. 2C).

To account for the differences in the effects of $\mathrm{Cl}^{-}$and $\mathrm{SO}_{4}^{-2}$ vanadates in gluconate media, we calculated, from the volume of $\mathrm{HCl}$ needed to adjust the $\mathrm{pH}$ of vanadate stock to 10.0 , the concentration of $\mathrm{Cl}^{-}$that would have been present in the final assay mixture when $200 \mu \mathrm{mol} / \mathrm{L} \mathrm{Cl}^{-}$vanadate was added to endosomes and obtained an estimate of about $0.4 \mathrm{mmol} / \mathrm{L} \mathrm{Cl}^{-}$. We also directly measured the concentration of $\mathrm{Cl}^{-}$when vanadate stocks were diluted to $200 \mu \mathrm{mol} / \mathrm{L}$ in water. In five such measurements, we obtained values of $0.42 \pm 0.02 \mathrm{mmol} / \mathrm{L} \mathrm{Cl}{ }^{-} . \mathrm{Cl}^{-}$was undetectable when $200 \mu \mathrm{mol} / \mathrm{L} \mathrm{SO}_{4}{ }^{-2}$ and $\mathrm{NaOH}$ vanadates were tested. To test whether less than or equal to $1 \mathrm{mmol} / \mathrm{L} \mathrm{Cl}^{-}$could alter acidification rates in $\mathrm{Na}$ gluconate media to the extent observed with $\mathrm{Cl}^{-}$vanadate, we measured initial rates of acidification of both 2-min and 10-minute endosomes in sodium gluconate or potassium gluconate media containing 0 to $5 \mathrm{mmol} / \mathrm{L} \mathrm{Cl}^{-}$. In 2 -min endosomes, $0.4 \mathrm{mmol} / \mathrm{L} \mathrm{Cl}^{-}$increased rates in sodium gluconate media by $192 \% \pm 20 \%(\mathrm{n}=4)$ and in potassium gluconate media by $29 \% \pm 12 \%(\mathrm{n}=6)$. Acidification rates measured over the entire range 0 to $5 \mathrm{mmol} / \mathrm{L} \mathrm{Cl}^{-}$were plotted as a percentage of rates in gluconate medium against medium chloride concentration in both $\mathrm{Na}^{+}$and $\mathrm{K}^{+}$media. These plots resembled rectangular hyperbolas and the function $y=([a x] /[b+x])+c$ was fit to the data. From the fitted curves we obtained estimates for the constants a, $\mathrm{b}$ and $\mathrm{c}$. The maximal overall rate of acidification $(\mathrm{a}+\mathrm{c})$ (as a percentage of rates in gluconate medium) and the $\mathrm{ED}_{50}$ for chloride (b) in $\mathrm{Na}^{+}$and $\mathrm{K}^{+}$media were $427 \%$ and $233 \%$ and $0.34 \mathrm{mmol} / \mathrm{L}$ and $1.89 \mathrm{mmol} / \mathrm{L}$, respectively. Using the fitted functions we calculated rates of acidification in $\mathrm{Na}^{+}$and $\mathrm{K}^{+}$media containing 0.42 $\mathrm{mmol} / \mathrm{L} \mathrm{Cl}^{-}$and found that these rates were increased
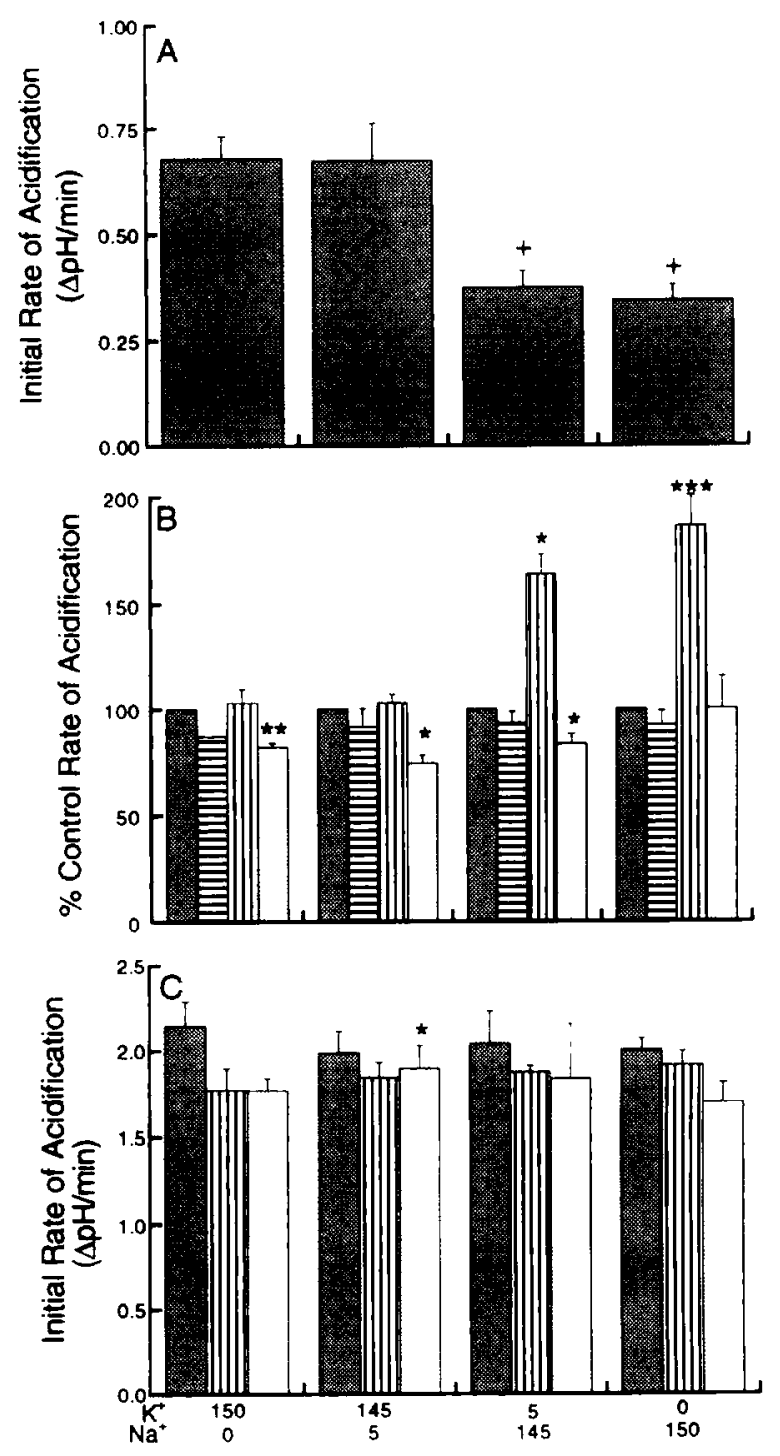

FIG. 2. Effects of three vanadate preparations on initial rate of acidification in early endosomes. For each endosome preparation, half of the endosomes were resuspended in $150 \mathrm{mmol} / \mathrm{L}$ potassium gluconate, $30 \mathrm{mmol} / \mathrm{L}$ BIS-TRIS (pH 7.0) and half in $150 \mathrm{mmol} / \mathrm{L}$ sodium gluconate, $30 \mathrm{mmol} / \mathrm{L}$ BIS-TRIS ( $\mathrm{pH} \mathrm{7.0)}$ ). Endosomes were preincubated in one of the buffers $(150 \mathrm{mmol} / \mathrm{L}$ salt, $5 \mathrm{mmol} / \mathrm{L} \mathrm{Mg}$ gluconate, $30 \mathrm{mmol} / \mathrm{L}$ BIS-TRIS [pH 7.0]) indicated on the $\mathrm{x}$-axis for 5 minutes at $22^{\circ} \mathrm{C}$ with or without $200 \mu \mathrm{mol} / \mathrm{L}$ vanadate. Endosomes resuspended in $\mathrm{K}$ gluconate buffer were used for experiments in high- $\mathrm{K}^{+}$media and endosomes resuspended in sodium gluconate buffer were used for experiments in high- $\mathrm{Na}^{+}$media. Results are expressed as mean \pm S.E.M. for values from three to seven separate preparations of endosomes. (A) Initial rates of acidification measured in control vesicles in gluconate medium. ${ }^{+} p<0.001$ compared with assays performed in potassium gluconate medium. (B) Effects of 200 $\mu \mathrm{mol} / \mathrm{L}$ vanadate on initial rates of acidification in gluconate medium Results are expressed as a percentage of rates in control assays in media of the same ionic composition. $\square$, controls; 园, $\mathrm{Cl}^{-}$-free boiled vanadate; (III $=\mathrm{Cl}^{-}$-containing boiled vanadate; $=\mathrm{NaOH}$ vanadate; ${ }^{*}, \mathrm{p}<0.05 ;^{* *}, \mathrm{p}<0.01 ;^{* * *} \mathrm{p}<0.005$ compared with control assays performed in buffers with same ionic composition. (C) Effects of 200 $\mu \mathrm{mol} / \mathrm{L}$ vanadate on initial rates of acidification assessed in $\mathrm{Cl}^{-}$. containing media. $\mathbf{D}$, controls; 四, boiled vanadate; $\mathbf{\square}=\mathrm{NaOH}$ vanadate. ${ }^{*}, \mathrm{p}<0.05$ compared with control assays performed in buffers with same ionic composition 


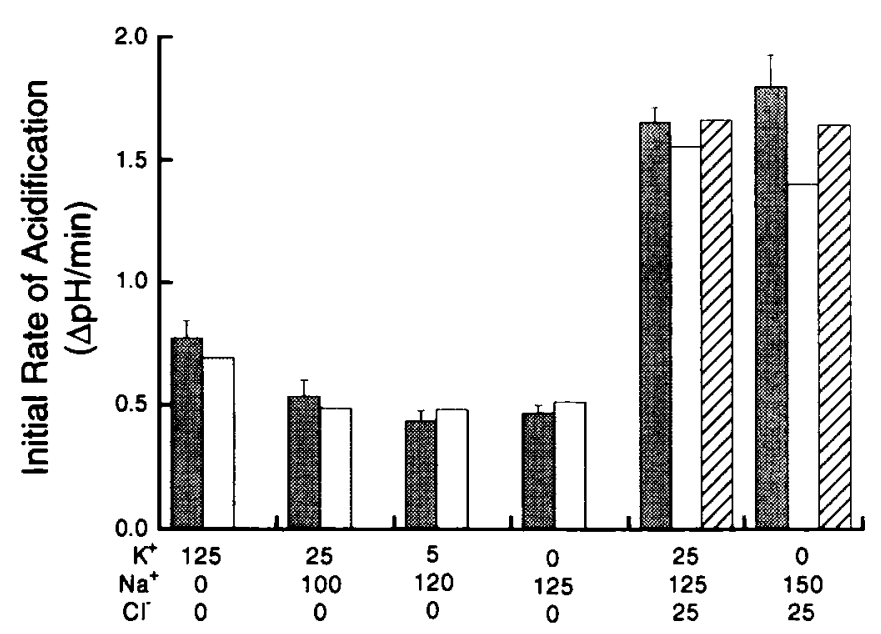

FIG. 3. Effects of boiled and $\mathrm{NaOH}$ vanadate in high- $\mathrm{Mg}^{+2}$ media on initial rate of acidification in early endosomes resuspended in either $140 \mathrm{mmol} / \mathrm{L}$ potassium gluconate (high $\mathrm{K}^{+}$assays) or in $140 \mathrm{mmol} / \mathrm{L}$ sodium gluconate (high- $\mathrm{Na}^{+}$assays) assayed in mixtures of $\mathrm{Na}^{+}$and $\mathrm{K}^{+}$with and without the presence of chloride as indicated on the $\mathrm{x}$-axis. All buffers contained $25 \mathrm{mmol} / \mathrm{L} \mathrm{Mg}$ gluconate to facilitate binding of vanadate to Na,K-ATPase. Endosomes were preincubated with or without $200 \mu \mathrm{mol} / \mathrm{L}$ vanadate for $5 \mathrm{~min}$ and assayed as described in the legend to Figure 1. Results are the mean ( \pm S.E.M. $[n \geq 3]$ ) of values from one to three separate preparations of endosomes. $\mathbf{\square}=$ controls; 圈 $=\mathrm{NaOH}$ vanadate; $\mathbb{Z}=\mathrm{Cl}^{-}$-containing boiled vanadate.

by $186 \%$ and $24.4 \%$, respectively, over rates in gluconate medium.

In further studies, acidification rates of $10-\mathrm{min}$ endosomes were increased by $0.4 \mathrm{mmol} / \mathrm{L} \mathrm{Cl}^{-}$by $166 \% \pm 40 \%(\mathrm{n}=5)$ in sodium gluconate media and by only $35 \% \pm 6 \%(\mathrm{n}=10)$ in potassium gluconate media. Finally, $0.4 \mathrm{mmol} / \mathrm{L} \mathrm{Cl}^{-}$appeared to be less effective in stimulating acidification when vanadate was present as, in one preparation of $10-\mathrm{min}$ endosomes, $0.4 \mathrm{mmol} / \mathrm{L}$ $\mathrm{Cl}^{-}$plus $200 \mu \mathrm{mol} / \mathrm{L} \mathrm{NaOH}$ vanadate-stimulated acidification by $50 \%$ less than $0.4 \mathrm{mmol} / \mathrm{L} \mathrm{Cl}^{-}$alone in $\mathrm{Na}^{+}$ medium (data not shown). Thus in all endosomes tested, small concentrations of medium $\mathrm{Cl}^{-}$increased acidification rates in $\mathrm{Na}^{+}$media much more (due to changes in both the incremental increase in acidification with $\mathrm{Cl}^{-}$ and the $\mathrm{ED}_{50}$ for $\mathrm{Cl}^{-}$) than in $\mathrm{K}^{+}$media. This resulted in rates of acidification in sodium gluconate with 0.4 $\mathrm{mmol} / \mathrm{L} \mathrm{Cl}{ }^{-}$that were similar to rates in potassium gluconate medium in the absence of measurable $\mathrm{Cl}^{-}$ (data not shown).

In additional studies, we also examined acidification rates in four preparations of FITC-dextran-loaded 10-min liver endosomes that were resuspended in 140 $\mathrm{mmol} / \mathrm{L} N$-methyl-D-glucamine gluconate medium and assayed in media, similar to those used for the experiments shown in Figure 2, containing $\mathrm{K}^{+}, \mathrm{Na}^{+}$or mixtures of the two with gluconate or $\mathrm{Cl}^{-}$. Initial rates of acidification in control studies were $0.31 \pm 0.05$ $\Delta \mathrm{pH} / \mathrm{min}$ in potassium gluconate medium and $0.76 \pm$ $0.05 \Delta \mathrm{pH} / \mathrm{min}$ in $\mathrm{KCl}$ medium. Ion substitution and exposure to $200 \mu \mathrm{mol} / \mathrm{L}$ vanadate had the same effects on acidification of these later-stage endosomes as on the 2-min endosomes illustrated in Figure 2 (data not shown).

As high concentrations of $\mathrm{Mg}^{+2}$ facilitate binding of vanadate to $\mathrm{Na}, \mathrm{K}$-ATPase $(12,20)$, we repeated our studies using media with $25 \mathrm{mmol} / \mathrm{L} \mathrm{Mg}^{+2}$. In highmagnesium media, vanadate had little effect on acidification in either the presence or absence of chloride (Fig. 3).

Steady-state ATP-dependent $\mathrm{pH}_{\mathrm{i}}$ in control endosomes was 6.04 to 6.08 in high-potassium gluconate media, 6.31 to 6.37 in high $\mathrm{Na}$ gluconate media and 5.91 to 5.98 in all media with $\mathrm{Cl}^{-}$(Table 1). These values paralleled the differences in initial rates of acidification measured in these same endosomes (Fig. 2A and C) and $\mathrm{pH}_{\mathrm{i}}$ was statistically significantly more alkaline in highsodium gluconate media than in high-potassium gluconate media $(\mathrm{p}<0.01)$. In the presence of vanadate, endosome ATP-dependent $\mathrm{pH}_{\mathrm{i}}$ also tended to be more alkaline than in control assays under all conditions tested and these differences achieved statistical significance in five of eight different experimental conditions (Table 1). As steady-state ATP-dependent $\mathrm{pH}_{\mathrm{i}}$ reflects the algebraic sum of rates of proton influx (initial rates of acidification) and proton efflux (proton leak rates), more alkaline steady-state $\mathrm{pH}_{\mathrm{i}}$ could result from decreases in proton influx or increases in proton efflux. Therefore, in four preparations of endosomes, we measured proton leak rates in potassium gluconate and sodium gluconate media with or without vanadate (Table 2). Leak rates (expressed as $\mathrm{pH}$ units per minute) were similar in all four experimental conditions and were not altered by exposure to vanadate. When leak rates were normalized for the intravesicular-to-extravesicular hydrogen ion gradient (a major driving force for proton efflux), efflux rates appeared to be faster in sodium gluconate media than in potassium gluconate media, primarily as the result of a similar leak rate driven by a smaller driving force (lesser hydrogen ion gradient) in the former experiments. We did not clamp membrane potential in these studies to measure the actual leak rates of our vesicles and it is probable that vesicles in sodium gluconate media exhibited a greater interior positive $\Delta \psi$ in conjunction with a more alkaline steady-state $\mathrm{pH}_{\mathrm{i}}$ (Table 1) than vesicles in potassium gluconate media as a result of poorer $\mathrm{Na}^{+}$permeability and this greater $\Delta \psi$ accounted for the faster normalized proton efflux rates (Table 2). Overall, however, these results indicate that vanadate itself had no effect on proton efflux and therefore the more alkaline $\mathrm{pH}_{\mathrm{i}}$ in vanadate-exposed endosomes probably reflects the modestly lower initial rates of acidification seen in most studies (Fig. 2).

To further examine whether vanadate itself inhibited endosome acidification, as has been suggested for chromaffin granule membranes (21), we measured maximum rates of acidification of these same 2-min endosomes in $140 \mathrm{mmol} / \mathrm{L} \mathrm{KCl}$ medium with or without 1 to $2 \mathrm{~mol} / \mathrm{L}$ vanadate. In two different preparations of endosomes, 1- and 2-mmol/L vanadate inhibited acidifi- 
TABLE 1. ATP-dependent steady-state $\mathrm{pH}_{\mathbf{i}}$

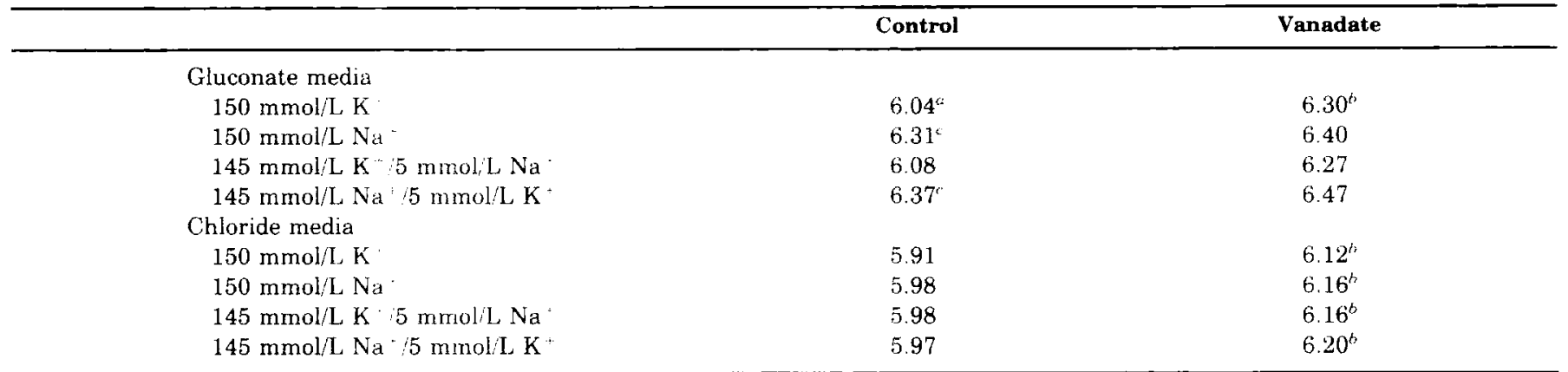

Values are from studies illustrated in Figure 1 and represent mean values from determinations in three to seven separate preparations of endosomes. $\mathrm{pH}_{\mathrm{i}}$ in endosomes before addition of MgATP averaged 6.89 and 7.04 ( $\mathrm{n}=36$ to 48 separate measurements, $\mathrm{p}=\mathrm{NS}$ ) for control and vanadate studies, respectively

"To calculate mean $\mathrm{pH}_{i}$ values, $\mathrm{pH}_{\mathrm{j}}$ values from individual assays were converted to hydrogen ion concentrations, mean \pm S.E.M. were calculated and mean values reconverted to $\mathrm{pH}$. Paired $\ell$ tests were used to compare hydrogen ion concentrations.

${ }^{B} \mathrm{p}<0.05$ vs. control assays.

$\mathrm{p}<0.01$ vs. assays in $\mathrm{K}$ gluconate media

Table 2. Proton leak rates

\begin{tabular}{|c|c|c|c|}
\hline Buffer & $\mathbf{n}$ & $\underset{\text { (units/min) }}{\Delta \mathrm{pH} / \mathrm{min}}$ & $\underset{(\text { units } / \min / \mu \mathrm{mol})}{\Delta \mathrm{pH} / \min /\left(\left(\mathrm{H}_{\mathrm{s}}+\right]\right)}$ \\
\hline Potassium gluconate & 5 & $0.14 \pm 0.01$ & $0.18 \pm 0.04$ \\
\hline Potassium gluconate $+200 \mu \mathrm{mol} / \mathrm{L}$ vanadate & 5 & $0.12 \pm 0.01$ & $0.19 \pm 0.04$ \\
\hline Sodium gluconate $+200 \mu$ mol $\mathrm{L}$ vanadate & 7 & $0.13 \pm 0.01$ & $0.37 \pm 0.05^{b}$ \\
\hline
\end{tabular}

Proton leak rates were measured as described in Materials and Methods in four different preparations of endosomes. Assays were performed in high- $\mathrm{K}^{*}\left(140 \mathrm{mmol} / \mathrm{L} \mathrm{K}\right.$ gluconate or $135 \mathrm{mmol} / \mathrm{L} \mathrm{K} / 5 \mathrm{mmol} / \mathrm{L} \mathrm{Na}{ }^{+}$gluconate $)$media or high Na $(140 \mathrm{mmol} / \mathrm{L}$ sodium gluconate or 135 $\mathrm{mmol} / \mathrm{L} \mathrm{Na}^{+} / 5 \mathrm{mmol} / \mathrm{L} \mathrm{K}^{+}$gluconate) media. Results in high $\mathrm{K}^{-}$media (or high $\mathrm{Na}^{+}$media) did not differ whether $5 \mathrm{mmol} / \mathrm{L} \mathrm{Na}^{+}$(or $\mathrm{K}^{-}$) was present or not; therefore results in high-K ${ }^{*}$ media were combined as were results in high $\mathrm{Na}^{+}$media.

u $\mathrm{p}=0.055$ vs. values in potassium gluconate media

${ }^{i} \mathbf{p}<0.05$ vs. values in potassium gluconate media with vanadate.

cation by $17 \%$ and $19 \%$, respectively, suggesting that vanadate does have mild inhibitory effects on the proton pump.

To confirm that these preparations of vanadateinhibited liver ATPase activity, we used two separate assays to measure total ATPase activity in our microsome preparation, which presumably contained plasma membranes and other intracellular organelles as well as endosomes. At $200 \mu \mathrm{mol} / \mathrm{L}$, both $\mathrm{NaOH}$ and $\mathrm{Cl}$. boiled vanadate inhibited ATPase activity in $\mathrm{Na}^{+}+\mathrm{K}^{+}$ media by $25 \%$ to $34 \%$, whereas $5 \mathrm{mmol} / \mathrm{L}$ ouabain (added to the extravesicular buffer and thus only accessible to the outside face of sealed vesicles) inhibited $15 \%$ to $20 \%$ of total ATPase activity (Fig. 4). In the same assays, $5 \mathrm{mmol} / \mathrm{L}$ ouabain combined with $200 \mu \mathrm{mol} / \mathrm{L}$ of either of the vanadate preparations inhibited ATPase activity by $36 \%$ to $39 \%$ and these values did not differ significantly from values measured in the presence of vanadate alone (Fig. 4). Ouabain plus vanadate more significantly inhibited ATPase activity, measured using the timed incubation assay, than ouabain alone $(p<0.05)$, probably as a result of vanadate's inhibitory effects on other ATPases.

We also studied the effects of other $\mathrm{Na}, \mathrm{K}$-ATPase inhibitors on acidification. Strophanthidin, a more lipophilic ouabain analog that rapidly penetrates cell membranes, has been used to inhibit $\mathrm{Na}, \mathrm{K}$-ATPase in inside-out erythrocyte membranes $(22,23)$. We therefore tested the effects of a 5-min exposure to $2 \mathrm{mmol} / \mathrm{L}$ strophanthidin on endosome acidification (control assays included equal volumes of the solvent ethanol). Initial rates of acidification in $25 \mathrm{mmol} / \mathrm{L}$ $\mathrm{KCl} / 115 \mathrm{mmol} / \mathrm{L}$ potassium gluconate medium was decreased to $70.2 \% \pm 2.0 \%(n=3)(p<0.05)$ of control values by strophanthidin exposure. In a single preparation of endosomes, exposure to $2 \mathrm{mmol} / \mathrm{L}$ strophanthidin inhibited acidification of endosomes in 150 $\mathrm{mmol} / \mathrm{L}$ potassium gluconate, $145 \mathrm{mmol} / \mathrm{L} \mathrm{K}^{+} / 5 \mathrm{mmol} / \mathrm{L}$ $\mathrm{Na}^{+}$gluconate, $145 \mathrm{mmol} / \mathrm{L} \mathrm{Na}^{+} / 5 \mathrm{mmol} / \mathrm{L} \mathrm{K}^{+}$gluconate and $150 \mathrm{mmol} / \mathrm{L}$ sodium gluconate buffers by $67 \%, 56 \%, 60 \%$ and $54 \%$, respectively, and inhibition was noted at strophanthidin concentrations as low as $0.25 \mathrm{mmol} / \mathrm{L}$ (data not shown). Strophanthidin did not increase proton leak rates in these same vesicles (data not shown). Strophanthidin $(1.5 \mathrm{mmol} / \mathrm{L})$ also inhibited ATPase activity in microsomes measured with the timed incubation assay by $37 \%(n=2)$. These results suggest that strophanthidin may directly interfere with vesi- 

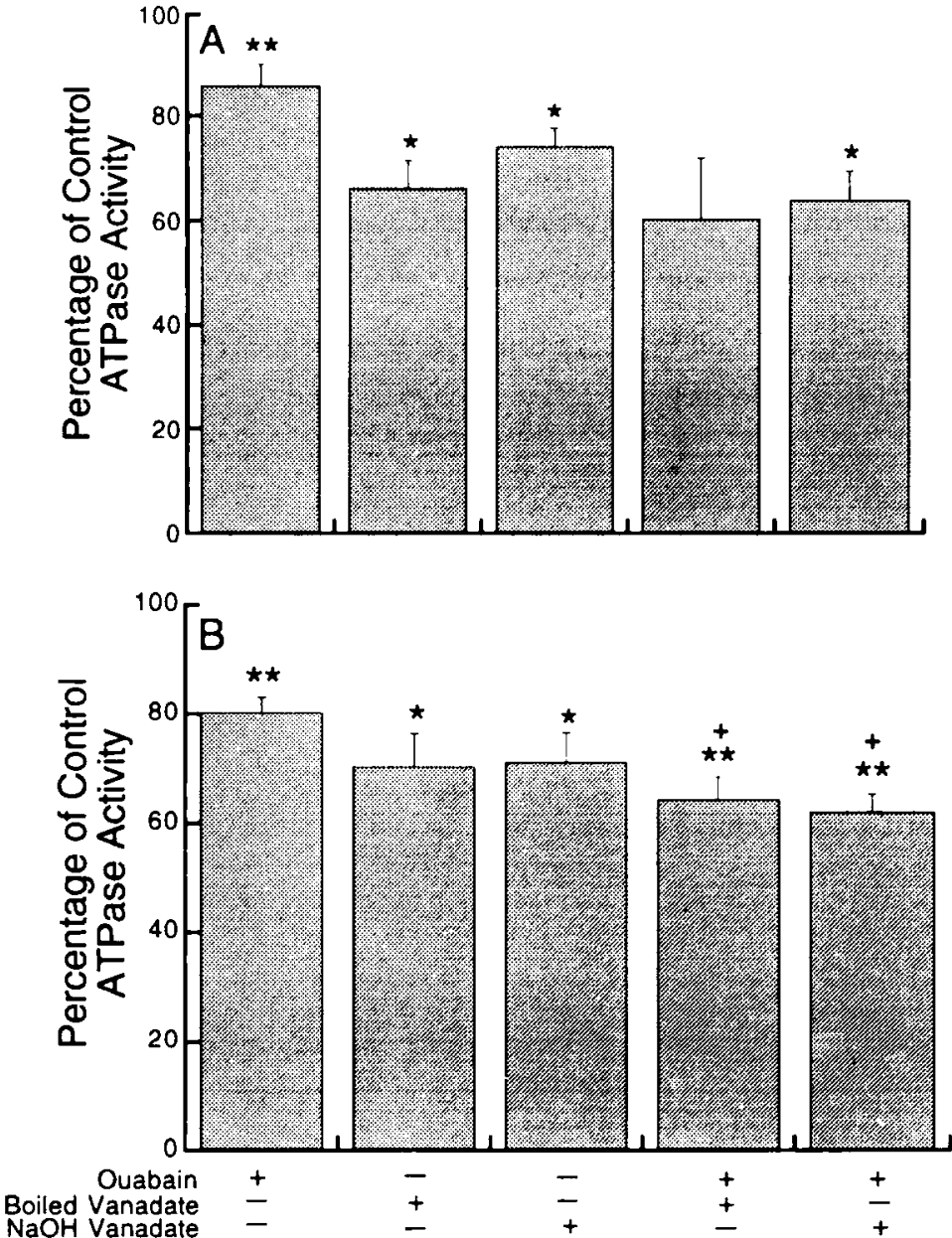

FIG. 4. Effects of ouabain, boiled and $\mathrm{NaOH}$ vanadate on liver ATPase activity measured as described in Materials and Methods. Microsomes were preincubated with $5 \mathrm{mmol} / \mathrm{L}$ ouabain or $200 \mu \mathrm{mol} / \mathrm{L}$ vanadate or both as indicated on the $\mathrm{x}$-axis. Results are expressed as mean $\pm \mathrm{S}$.E.M. $(n=4)$ percentage of values obtained in concurrent control assays. ATPase was measured by: (A) coupled enzyme assay; (B) timed incubation assay. ${ }^{*}, \mathrm{p}<0.05 ;{ }^{* *}, \mathrm{p}<0.01$ compared with control assays; ${ }^{+}=\mathrm{p}<0.05$ compared with assays containing ouabain.

cle acidification as well as inhibiting $\mathrm{Na}, \mathrm{K}-\mathrm{ATPa}$.

Ouabain is poorly membrane-permeant and, because the ouabain binding site of Na,K-ATPase would be expected to be on the internal face of endocytic vesicles, we prepared endosomes that were loaded with ouabain by endocytosis using the perfused liver system. We prepared endosomes after a 5-min rather than 2-min exposure to FITC-dextran to maximize the fluorescein signal. With addition of $1 \mathrm{mmol} / \mathrm{L}$ nitroprusside to all perfusates, perfusion with ouabain-containing media did not alter perfusion pressure or flow rates in our system and these parameters remained stable throughout all perfusions (data not shown). Bile flow during the second perfusion period averaged $1.79 \pm 0.15$ $\mu \mathrm{l} / \mathrm{min} / \mathrm{gm}$ liver ( $\mathrm{n}=8$ measurements from four perfusions) in control studies and $1.76 \pm 0.09 \mu 1 / \mathrm{min} / \mathrm{gm}$ liver ( $\mathrm{n}=9$ measurements from four perfusions) in ouabain studies and these values were not significantly different. Although ouabain is excreted in bile by rat liver and its osmotic effects increase bile flow (16), we failed to observe an increase in bile flow in ouabain-exposed livers, probably as ouabain was present for too brief a time period.

In these perfused liver endosomes, as in 2-min endosomes prepared from intact rats, the initial rate of acidification was higher in high- $\mathrm{K}^{+}$medium in the absence of $\mathrm{Cl}^{-}\left(140 \mathrm{mmol} / \mathrm{L} \mathrm{K} \mathrm{K}^{+} ; 135 \mathrm{mmol} / \mathrm{L}\right.$ $\mathrm{K}^{+} / 5 \mathrm{mmol} / \mathrm{L} \mathrm{Na}^{+}$) compared to high- $\mathrm{Na}^{+}$media (140 $\mathrm{mmol} / \mathrm{L} \mathrm{Na}^{+} ; 135 \mathrm{mmol} / \mathrm{L} \mathrm{Na}^{+} / 5 \mathrm{mmol} / \mathrm{L} \mathrm{K}^{+}$) and these differences achieved statistical significance for assays in $135 \mathrm{mmol} / \mathrm{L} \mathrm{Na} \mathrm{Na}^{+} / 5 \mathrm{mmol} / \mathrm{L} \mathrm{K}^{+}$gluconate medium ( $p<0.05$ ) (Fig. 5). Ouabain-loaded endosomes acidified at a rate $41 \%$ to $48 \%$ lower than control endosomes in $140 \mathrm{mmol} / \mathrm{L} \mathrm{Na}^{+}$or $135 \mathrm{mmol} / \mathrm{L} \mathrm{Na}^{+} / 5 \mathrm{mmol} / \mathrm{L} \mathrm{K}^{+}$ media and at a rate $21 \%$ to $24 \%$ lower than controls in $140 \mathrm{mmol} / \mathrm{L} \mathrm{K}^{+}$or $135 \mathrm{~K}^{+} / 5 \mathrm{mmol} / \mathrm{L} \mathrm{Na}^{+}$media (Fig. 5). In chloride-containing media, initial rates of acidification in control studies were $53 \%$ to $56 \%$ faster than in gluconate media $(\mathrm{p}<0.01$ for $\mathrm{KCl}$ compared with potassium gluconate media) and ouabain-loaded endo- 


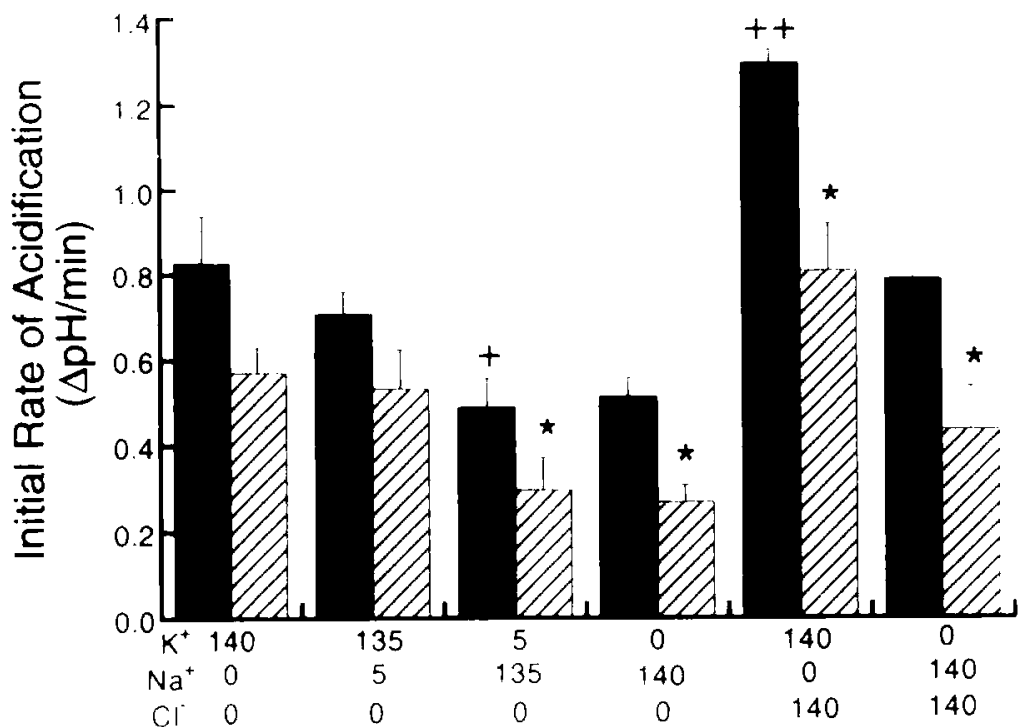

FIG. 5. Effects of $5 \mathrm{mmol} / \mathrm{L}$ ouabain, internalized during liver perfusions, on the initial rate of acidification of endosomes resuspended in either $140 \mathrm{mmol} / \mathrm{L}$ potassium gluconate or in $140 \mathrm{mmol} / \mathrm{L}$ sodium gluconate media and assayed in mixtures of $\mathrm{Na}^{+}$and $\mathrm{K}^{+}$with and without the presence of chloride as indicated on the $\mathrm{x}$-axis. Endosomes resuspended in potassium gluconate buffer were used for experiments in high- $\mathrm{K}$ media and endosomes resuspended in sodium gluconate buffer were used for experiments in high-Na ${ }^{+}$media. Results are mean \pm S.E.M. of values from four paired endosome preparations. compared with control assays performed in buffers with the same ionic composition; ${ }^{+}, \mathrm{p}<0.05,{ }^{-}, \mathrm{p}<0.01$ compared with control assays in potassium gluconate medium.

somes acidified $38 \%$ to $46 \%$ slower than control endosomes (Fig. 5) $(p<0.01)$. Steady-state ATP-dependent $\mathrm{pH}_{\mathrm{i}}$ averaged $0.17 \mathrm{pH}$ units more alkaline in ouabainloaded endosomes compared with controls (data not shown) in all of the media tested.

\section{DISCUSSION}

The $\beta$-subunit of $\mathrm{Na}, \mathrm{K}$-ATPase has been immunologically localized to early rat liver endosomes $(10,11)$ and, because liver is one of the most active endocytic organs and hepatic endosomes form from the basolateral hepatocyte membrane where functional $\mathrm{Na}, \mathrm{K}$-ATPase is located $(4,24)$, we initiated this study to determine whether $\mathrm{Na}, \mathrm{K}$-ATPase regulates acidification of early rat liver endosomes. Endosomes are oriented "inside-out" with respect to plasma membranes and therefore the ATP binding site of Na,K-ATPase should be located on the exterior face of the endosome, the ouabain binding site on the interior face and the pump would be expected to transport sodium into and potassium out of the vesicle interior, thereby generating a small interior positive membrane potential $(\Delta$,$) . Because endosomes are$ acidified by an electrogenic proton pump (1-3) and the rate of acidification is strongly influenced by $\Delta \psi(3,25)$, the presence of functional and electrogenic $\mathrm{Na}, \mathrm{K}$ ATPase in liver endosomes would be expected to increase $\Delta \psi$, to decrease rates of acidification and to increase steady-state ATP-dependent $\mathrm{pH}_{\mathrm{j}}$. We have shown previously that $\mathrm{Cl}^{-}$is a permeable anion that at concentrations greater than or equal to $25 \mathrm{mmol} / \mathrm{L}$ effectively neutralizes the charge of pumped protons in rat liver endosomes, resulting in a $\Delta \psi$ close to zero $(3,14)$.
Therefore, if Na,K-ATPase does function in rat liver endosomes, we would expect endosome acidification to be reduced in media containing $\mathrm{Na}^{+}$and $\mathrm{K}^{+}$(but neither cation alone) in the absence, but not presence, of $\mathrm{Cl}$. Na,K-ATPase inhibitors, including ouabain, vanadate and strophanthidin, would be expected to increase acidification rates under these same conditions.

For these studies we chose to study very early rat liver endosomes because those were the most likely to exhibit functional Na,K-ATPase $(5,7)$. Endosomes prepared from intact rats after a 2-minute intravenous exposure to FITC-dextran were the earliest vesicles we could reproducibly prepare that contained sufficient FITCdextran for reliable measurement of $\mathrm{pH}$. In the perfused liver, endosomes prepared after a 2-min exposure to FITC-dextran contained insufficient fluorescence for accurate measurements; therefore for these studies we used a 5-min exposure to FITC-dextran. We also chose to examine a wider array of experimental conditions, including a variety of ion substitutions and various $\mathrm{Na}$,K-ATPase inhibitors, than had previously been used.

Because vanadate exists in several slowly equilibrating species $(12,20)$ and binding to $\mathrm{Na}, \mathrm{K}$-ATPase may vary with the concentration of $\mathrm{Mg}^{+2}, \mathrm{Na}^{+}$and $\mathrm{K}^{+}$ (12), we used several different methods of preparing vanadate and we tested the effects of vanadate in media with high and low concentrations of all of these cations. Sodium orthovanadate was either dissolved in concentrated $\mathrm{NaOH}$ to obtain monomeric $\mathrm{VO}_{4}^{-3}$ or orthovanadate was dissolved in water, adjusted to $\mathrm{pH} 10$ with acid and boiled. Because considerable concentrated acid was required to reach $\mathrm{pH} 10$ in the second method, 
leading to the presence of about $0.4 \mathrm{mmol} / \mathrm{L}$ anion in the final assay buffer, we prepared and tested boiled vanadate that was $\mathrm{pH}$ adjusted with $\mathrm{HCl}$ (13) or with $\mathrm{H}_{2} \mathrm{SO}_{4}$. Vanadate prepared by either method consistently inhibited ATPase activity in a liver microsomal preparation that contained endosomes as well as other intracellular organelles and plasma membranes (Fig. 4) and inhibited ATPase activity to a greater extent than 5 $\mathrm{mmol} / \mathrm{L}$ ouabain. For these studies we used frozen and thawed microsomes, which may improve access of ouabain to the interior face of vesicular structures. The ATPase assays were performed using conditions under which $\mathrm{Na}$,K-ATPase would be maximally active; however, a variety of other ATPases would also be active, including the endosome proton pump. Indeed, the greater inhibitory effect of vanadate compared to ouabain probably reflects the inhibitory effects of vanadate on a number of P-type ATPases, including both $\mathrm{Na}, \mathrm{K}-\mathrm{ATP}$ ase and Ca-ATPase. Strophanthidin exhibited effects similar to ouabain but appeared to be a more potent inhibitor ( $37 \%$ vs. $20 \%$ inhibition), perhaps as a result of its greater lipid solubility and ability to diffuse across membranes to reach its binding site in any remaining sealed inside-out vesicles.

Overall, our results do not support our hypothesis that early rat liver endosomes exhibit functional $\mathrm{Na}, \mathrm{K}$ ATPase. Although acidification was faster in $\mathrm{K}^{+}$media than in $\mathrm{Na}^{+}$media, mixtures of the two did not decrease acidification, even in $\mathrm{Cl}^{-}$-free media. Vanadate, in $\mathrm{Cl}^{-}$-free gluconate media, had similar inhibitory effects on acidification, even in buffers containing only $\mathrm{Na}^{+}$or only $\mathrm{K}^{+}$. As shown in Figure 2B, $\mathrm{Cl}^{-}$-containing boiled vanadate did increase acidification of endosomes in high- $\mathrm{Na}^{+}$buffers (but not in high $\mathrm{K}^{+}$buffers); however, this effect probably resulted from the small concentrations (about $0.4 \mathrm{mmol} / \mathrm{L}$ ) of $\mathrm{Cl}^{-}$present in buffers containing $200 \mu \mathrm{mol} / \mathrm{L}$ boiled $\mathrm{Cl}^{-}$vanadate. Both 0.4 $\mathrm{mmol} / \mathrm{L} \mathrm{Cl}^{-}$and $200 \mu \mathrm{mol} / \mathrm{L} \mathrm{Cl}^{-}$vanadate (which contained $0.42 \mathrm{mmol} / \mathrm{L} \mathrm{Cl}^{-}$) increased acidification far more in $\mathrm{Na}^{+}$than in $\mathrm{K}^{+}$media; however, in $\mathrm{Na}^{+}$media, the direct addition of $0.4 \mathrm{mmol} / \mathrm{L} \mathrm{Cl}^{-}$increased acidification more (by $166 \%$ to $192 \%$ ) than the addition of $\mathrm{Cl}^{-}$ vanadate containing the same amount of $\mathrm{Cl}^{-}$(by about 90\%). This difference could, in part, reflect the concomitant inhibitory effects of vanadate on acidification rates as shown in Figure 2.

Alternative explanations for our findings include consideration of other modes of $\mathrm{Na}, \mathrm{K}$-ATPase function. It is known that, in the absence of $\mathrm{K}^{+}, \mathrm{Na}, \mathrm{K}$-ATPase can function as an electroneutral $\mathrm{Na}^{+} / \mathrm{H}^{+}$exchanger and, in the absence of $\mathrm{Na}^{+}$, function as a $\mathrm{K}^{+} / \mathrm{H}^{+}$exchanger if $\mathrm{pH}$ on the proton binding side is at least 6.0 or lower $(22,23)$. Thus, in $\mathrm{Na}$ gluconate medium without $\mathrm{K}^{+}$, acidification might be lower than acidification in $\mathrm{K}^{+}$or $\mathrm{K}^{+}+\mathrm{Na}^{+}$medium and increased by vanadate if $\mathrm{Na}, \mathrm{K}-$ ATPase functioned to exchange external $\mathrm{Na}^{+}$for internal $\mathrm{H}^{+}$. However, this is an unlikely explanation for our results because, if so, we would also expect acidification to be lower in $\mathrm{NaCl}$ medium than in $\mathrm{KCl}$ medium and acidification in $\mathrm{Na}^{+}$medium with or without $\mathrm{Cl}^{-}$to be increased consistently by vanadate and neither of these findings was observed (Fig. 2). Thus, the overall results of our studies using ion substitution and vanadate indicate that functional $\mathrm{Na}, \mathrm{K}$-ATPase is not present in early rat liver endosomes and this enzyme does not regulate acidification.

Vanadate, however, tended to decrease acidification ( $8 \%$ to $19 \%$ ) in all media tested and increased ATPdependent $\mathrm{pH}_{\mathrm{i}}$, suggesting that vanadate might have some inhibitory effects on the endosome proton pump at high concentrations. Recently Beltran and Nelson (21) noted that vanadate appeared to directly inhibit the proton pump of chromaffin granule membranes and yeast vacuoles with complete inhibition of acidification noted at 4 to $5 \mathrm{mmol} / \mathrm{L}$ vanadate and $50 \%$ inhibition at $0.5 \mathrm{mmol} / \mathrm{L}$ vanadate. In a few studies we tested higher concentrations of vanadate, but we found that 1 to 2 $\mathrm{mmol} / \mathrm{L}$ vanadate only inhibited rat liver endosome acidification by $17 \%$ to $19 \%$. The differences between the effects noted by Beltran and Nelson and ourselves may reflect differences in the proton pumps of the vesicles tested, but, more likely, reflect differences in the methods used to assess rates of acidification. Beltran measured changes in absorbance of the fluorescent dye acridine orange, whereas in our studies we assessed vesicle $\mathrm{pH}$ directly from the fluorescence ratio of fluorescein. Our studies have shown that the fluorescein fluorescence method measures low rates of acidification more accurately and that studies using acridine orange may amplify the effects of various inhibitors (Van Dyke RW, Unpublished observations, 1988). In addition, vanadate absorbs at $492 \mathrm{~nm}$ (Van Dyke RW, Unpublished observations, 1993) and therefore changes in vanadate concentration may affect rates of acidification measured with acridine orange. Thus we conclude that vanadate may directly inhibit the rat liver endosome proton pump, but only to a modest degree and only at high concentrations.

Because vanadate appeared to have a variety of effects on endosome acidification, we also used two agents thought to be specific for Na,K-ATPase-namely, strophanthidin and ouabain. Surprisingly we found evidence that both agents directly inhibited endosome acidification in all media tested. We used high concentrations of both of these agents $(5 \mathrm{mmol} / \mathrm{L}$ ouabain and $2 \mathrm{mmol} / \mathrm{L}$ strophanthidin), because rat liver $\mathrm{Na}, \mathrm{K}$-ATPase is known to be insensitive to ouabain and we found consistently inhibitory effects when the interior face of endosomes was exposed to either drug. Although strophanthidin is known to inhibit other P-type ATPases (26), including the fungal plasma membrane electrogenic proton pump, ouabain is thought to be a highly specific inhibitor of Na,K-ATPase. Our findings contrast with those of others who found that $1 \mathrm{mmol} / \mathrm{L}$ ouabain $(5,6)$ and $200 \mu \mathrm{mol} / \mathrm{L}$ strophanthidin (5) internalized into endosomes increased acidification, consistent with inhibition of functional $\mathrm{Na}, \mathrm{K}$-ATPase. The inhibitory effects of ouabain and strophanthidin we observed in rat liver endosomes may reflect species differences or effects of very high concen- 
trations of the drugs. Further studies will be needed to resolve these issues.

Overall our findings contrast with observations by at least three other groups (5-7) who observed changes in endosome acidification with vanadate and ouabain consistent with the presence of functional $\mathrm{Na}, \mathrm{K}$-ATPase in early endosomes from Chinese hamster ovary cells (5), epidermoid carcinoma cells (7) and Swiss 3T3 fibroblasts (6). However, others $(8,9)$-like ourselves - could not document functional $\mathrm{Na}, \mathrm{K}$-ATPase in endosomes from erythroleukemia cells or rabbit kidney and, in unpublished observations, one group noted no apparent $\mathrm{Na}, \mathrm{K}$ ATPase activity in rat liver endosomes (27). These differences probably reflect primarily tissue and species differences; however, the composition of vanadate used in previous studies is not known and may have affected some of the results of other investigators (5) who prepared boiled vanadate using the same method we did (13). However, tissue and species differences in regulation of endosome acidification may be common because, in contrast to findings that early endosomes from Chinese hamster ovary cells acidify more slowly than later endosomes (5)-due in part to the effects of $\mathrm{Na}, \mathrm{K}$-ATPase - we found that early rat liver endosomes acidify faster than later endosomes, including multivesicular bodies and lysosomes $(14,17)$.

Thus, although the $\beta$ subunit of $\mathrm{Na}, \mathrm{K}$-ATPase has been localized to early rat liver endosomes, our findings suggest that it is not functional. Either there is no corresponding $\alpha$ subunit in these vesicles or the pump has been inactivated, perhaps by changes in lipid fluidity analogous to the inactivation of $\mathrm{Na}, \mathrm{K}$-ATPase in rat liver canalicular membranes (24).

Acknowledgments: We would like to thank Ms. Cheryl Swanigan for her secretarial assistance.

\section{REFERENCES}

1. Van Dyke RW. Acid transport by intracellular vesicles. J Intern Med 1990;228:41-46.

2. Forgac M. Structure and function of vacuolar class of ATP-driven proton pumps. Physiol Rev 1989;69:765-796.

3. Van Dyke RW. Proton pump-generated electrochemical gradients in rat liver multivesicular bodies. J Biol Chem 1988;263:26032611.

4. Sellinger M, Barrett C, Malle P, Gordon ER, Boyer JL. Cryptic $\mathrm{Na}^{+}, \mathrm{K}^{+}$-ATPase activity in rat liver canalicular plasma membranes: evidence for its basolateral origin. HEPATOLOGY 1990;11:223-229.

5. Fuchs $\mathrm{R}$, Schmid S, Mellman I. A possible role for $\mathrm{Na}^{+}$, $\mathrm{K}^{+}$-ATPase in regulating ATP-dependent endosome acidification. Proc Natl Acad Sci U S A 1989;86:539-543.

6. Zen K, Biwersi J, Periasamy N, Verkman AS. Second messengers regulate endosomal acidification in Swiss 3T3 fibroblasts. J Cell Biol 1992;119:99-110.

7. Corley Cain C, Sipe DM, Murphy RF. Regulation of endocytic pH by the $\mathrm{Na}^{+}, \mathrm{K}^{+}$-ATPase in living cells. Proc Natl Acad Sci U S A 1989;86:544-548.

8. Sipe DM, Jersurum A, Murphy RF. Absence of $\mathrm{Na}^{+}, \mathrm{K}^{+}$-ATPase regulation of endosomal acidification in K562 erythroleukemia cells. J Biol Chem 1991;266:3469-3474.

9. Hilden SA, Ghoshroy KB, Madias NE. $\mathrm{Na}^{+}-\mathrm{H}^{+}$exchange but not $\mathrm{Na}^{+}-\mathrm{K}^{+}$-ATPase, is present in endosome-enriched microsomes from rabbit renal cortex. Am J Physiol 1990;258:F1311-F1319.

10. Casciola-Rosen LA, Hubbard AL. Lumenal labeling of rat hepatocyte early endosomes. J Biol Chem 1992;267:8213-8221.

11. Casciola-Rosen LA, Renfrew CA, Hubbard AL. Lumenal labeling of rat hepatocyte endocytic compartments. J Biol Chem 1992;267: 11856-11864.

12. Nechay BR, Nanninga LB, Nechay PSE, Post RL, Grantham JJ, Macara IG, Kubena LF, et al. Role for vanadium in biology. Fed Proc 1986;45:123-132.

13. Goodno CC. Myosin active-site trapping with vanadate ion. Methods Enzymol 1982;85:116-123.

14. Van Dyke RW. Acidification of rat liver lysosomes: quantitation and comparison to endosomes. Am J Physiol 1993;265:C901-C917.

15. Van Dyke RW, Stephens JE, Scharschmidt BF. Effects of ion substitution on bile acid-dependent and -independent bile formation by rat liver. J Clin Invest 1982;70:505-517.

16. Thomsen OO, Larsen JA. Comparison of vanadate and ouabain effects on liver hemodynamics and bile production in the perfused rat liver. J Pharmacol Exp Ther 1982;221:197-205.

17. Van Dyke RW, Root KV. Ethynyl estradiol decreases acidification of rat liver endocytic vesicles. HEPATOLOGY 1993;18:604-613.

18. Scharschmidt BF, Keeffe EB, Blankenship NM, Ockner RK. Validation of a recording spectrophotometric method for measurement of membrane-associated $\mathrm{Mg}$ - and NaK-ATPase activity. J Lab Clin Med 1979;93:790-799.

19. Murphy VA. Method for determination of sodium, potassium, calcium, magnesium, chloride and phosphate in the rat choroid plexus by flame atomic absorption and visible spectroscopy. Anal Biochem 1987;161:144-151.

20. Nechay BR. Mechanisms of action of vanadium. Annu Rev Pharmacol Toxicol 1984;24:501-524.

21. Beltran C, Nelson N. The membrane sector of vacuolar $\mathrm{H}^{+}$)ATPase by itself is impermeable to protons. Acta Physiol Scand Suppl 1992;607:41-47.

22. Polvani C, Blostein R. Protons as substitutes for sodium and potassium in the sodium pump reaction. J Biol Chem 1988;263: 16757-16763

23. Blostein R, Polvani C. Altered stoichiometry of the Na,K-ATPase. Acta Physiol Scand 1992;146:105-110.

24. Sutherland E, Dixon BS, Leffert HL, Skally H, Zaccaro L, Simon FR. Biochemical localization of hepatic surface-membrane $\mathrm{Na}^{+}, \mathrm{K}^{+}$-ATPase activity depends on membrane lipid fluidity. Proc Natl Acad Sci U S A 1988;85:8673-8677.

25. Andersen OS, Silveira JEN, Steinmetz PR. Intrinsic characteristics of the proton pump in the luminal membrane of a tight urinary epithelium. J Gen Physiol 1985;86:215-234.

26. Xu K. Inhibition of $\mathrm{H}^{+}$-transporting ATPase, $\mathrm{Ca}^{2+}$-transporting ATPase and $\mathrm{H}^{+} / \mathrm{K}^{+}$-transporting ATPase by strophanthidin. Biochem Biophys Acta 1992;1159:109-112.

27. Fuchs R, Male P, Mellman I. Acidification and ion permeabilities of highly purified rat liver endosomes. I Biol Chem 1989;264: 2212-2220. 